\title{
SISTEM PROMOSI MADU DALAM PERSPEKTIF HUKUM ISLAM (Studi di Gampong Buloh Seuma Aceh Selatan)
}

\author{
Rusnawati \\ Universitas Islam Negeri (UIN) Ar-Raniry Banda Aceh \\ e-mail : roesna1977@gmail.com \\ Cut Ayu Mauidhah \\ Universitas Islam Negeri (UIN) Ar-Raniry Banda Aceh \\ e-mail : mauidhahcutayu@yahoo.com
}

\begin{abstract}
The development of the use of promotional tools in vulnerable conditions, even today consumers are faced with what is known as consumer ignorance, namely the inability of consumers to select information due to technological advances and product diversity, so that this can be misused by business actors. Honey is a food source of energy that contains simple sweets so that it can be immediately utilized by the body. The honey packaging system in this village still uses bottles of fresh drinks, jarken, and other packaging to wrap honey and market it outside. Such conditions can reduce farmers' trust in Buloh Seuma honey. This study aims to find out how the promotion system used by Buloh Seuma Gampong South Aceh honey farmers, to find out what obstacles faced by Gampong Buloh Seuma honey farmers in South Aceh in the process of honey promotion. This type of research aims to make a systematic, factual and accurate description of the facts and characteristics of a particular population or object. Data collection techniques used in this study were observation, interview, and documentation techniques. Honey promotion system at Buloh Seuma Village still uses a traditional promotion system, meaning that it has not used commercial sources (advertisements, salespeople, suppliers, packaging, displays in stores), so marketing is carried out only through information by word of mouth. The centralized organization system is often used because companies do not have many types and brands of products to advertise or promote. So the conclusion in promoting honey in Buloh Seuma is not using advertising methods or the like that can invite consumers to buy it, but on the contrary the honey sellers only inform by word of mouth.
\end{abstract}

Keywords: Promotion, Honey and Islamic Law

Nur El-Islam, Volume 5, Nomor 2, Oktober 2018 


\begin{abstract}
Abstrak
Perkembangan pemakaian alat promosi dalam kondisi yang rawan, bahkan pada zaman sekarang konsumen dihadapkan pada apa yang dikenal dengan consumer ignorance, yaitu ketidakmampuan konsumen menyeleksi informasi akibat kemajuan teknologi dan keragaman produk, sehingga hal ini dapat disalahgunakan oleh para pelaku usaha. Madu adalah bahan makanan sumber energi yang mengandung gulagula sederhana sehingga dapat segera dimanfaatkan oleh tubuh. Sistem pengemasan madu di desa ini masih menggunakan botol minuman segar, jarken, dan kemasan lainnya untuk membungkus madu dan dipasarkan ke luar. Keadaan demikian dapat mengurangi kepercayaan petani terhadap madu Buloh Seuma. Penelitian ini bertujuan untuk mengetahui bagaimana sistem promosi yang digunakan petani madu Gampong Buloh Seuma Aceh Selatan, untuk mengetahui kendala apa yang dihadapi petani madu Gampong Buloh Seuma Aceh Selatan dalam proses promosi madu. Jenis penelitian ini bertujuan membuat deskripsi secara sistematis, factual dan akurat tentang fakta-fakta dan sifat-sifat populasi atau objek tertentu. Teknik pengumpulan data yang digunakan dalam penelitian ini yaitu teknik observasi, wawancara, dan dokumentasi. Sistem promosi madu pada Gampong Buloh Seuma masih menggunakan sistem promosi tradisional artinya belum menggunakan sumber komersial (iklan, wiraniaga, penyalur, kemasan, pajangan di toko), jadi pemasaran yang dilakukan hanya menyampaikan informasi melalui mulut ke mulut. Adapun sistem organisasi terpusat sering digunakan karena perusahaan tidak memiliki banyak jenis dan merek produk untuk diiklankan atau di promosikan. Maka kesimpulannya dalam mempromosikan madu di gampong Buloh Seuma tidak menggunakan metode iklan atau sejenisnya yang dapat mengundang para konsumen untuk membelinya, akan tetapi sebaliknya para penjual madu hanya menginformasikan melalui mulut ke mulut.
\end{abstract}

Kata kunci: Promosi, Madu, dan Hukum Islam.

\title{
A. Pendahuluan
}

1. Latar Belakang Masalah

Indonesia memiliki kondisi alam yang sangat mendukung perkembangan budidaya lebah madu. Kondisi tanah yang cukup subur memungkinkan pertumbuhan berbagai jenis tanaman yang dapat dimanfaatkan sebagai sumber pakan lebah. Produk yang dihasilkan lebah madu dibutuhkan untuk memenuhi konsumsi tiap individu dalam menjaga kesehatan, pengobatan, serta diperlukan juga bagi industri farmasi dan pangan. Peluang pasar produk lebah madu dapat dimanfaatkan dengan baik jika didukung pemasaran yang efisien. Pemasaran merupakan indikator keberhasilan dari yang dihasilkan 
sehingga pemasaran tidak dapat dipisahkan dengan produksi. Produksi lebah madu selalu mengalami fluktuasi karena tergantung dengan musim bunga dari tanaman pekan lebah. Lebah madu adalah insekta sosial yang selalu hidup dalam suatu keluarga besar, yang disebut koloni lebah. Setiap sarang dihuni oleh satu koloni, dalam satu koloni terdapat hanya satu ratu (Queen), beberapa ratus lebah jantan, beberapa ratus ribu lebah pekerja, ditambah dengan penghuni dalam bentuk telur, larva dan pupa. Yang mana madu juga merupakan bahan makanan sumber energi yang mengandung gula-gula sederhana sehingga dapat segera dimanfaatkan oleh tubuh.

Di Indonesia terdapat beberapa daerah yang mempunyai tradisi pada saat pengambilan madu, salah satunya yaitu Buloh Seuma, daerah terpencil yang berada dibibir pantai Samudera Hindia dan perbatasan langsung dengan kawasan ekosistem Leuser itu memiliki 30.600 hektar dan dihuni oleh 834 penduduk dalam tiga desa: Gampong Raket, Kuta Padang, dan Gampong Teungoh. Desa yang berjarak sekitar $38 \mathrm{~km}$ dari pusat kecamatan Trumon kabupaten Aceh Selatan itu merupakan penghasil madu asli. Buloh- seuma di Kecamatan Trumon, merupakan daerah madu lebah alami. Produksi madu harta keluarga yang diwariskan secara turun temurun di sini bukanlah sawah atau toko. Satu keluarga hanya mewariskan pohon pulai yang ditumpangi lebah kepada anggota keluarganya untuk dipelihara dan begitu seterusnya.

Dalam kajian ini peneliti bermaksud untuk melakukan penelitian di daerah Buloh Seuma, dimana di Buloh Seuma merupakan suatu daerah yang telah terkenal dengan madu asli. Namun, dengan adanya madu asli di Buloh Seuma tetapi masih ada masyarakat lain yang belum yakin dengan madu asli tersebut.

Berdasarkan pengamatan dan studi pendahuluan yang dilakukan peneliti terhadap madu asli, peneliti berkeinginan untuk mengetahui apa penyebabnya sehingga masyarakat lain masih belum yakin dengan madu asli Buloh Seuma. Karena madu asli Buloh Seuma telah terkenal tetapi masih ada keraguan terhadap masyarakat lain.

Pada saat ini kondisi petani madu di Buloh Seuma masih semangat untuk memanenkan madu walaupun ada isu yang 
menyatakan bahwa madu Buloh Seuma masih ada keraguan. Perkembangan teknologi semakin canggih membuat masyarakat ikut beralih dan sadar bahwa madu mempunyai banyak khasiat-khasiat, hal tersebut bisa diperoleh dari promosi yang digunakan agen (pemilik madu) melalui media- media komersial. Sistem pengambilan madu yang masih tergolong tradisional masih diterapkan di desa ini, tidak hanya itu dilihat dari cara pengolahan madu juga masih menerapkan nilai-nilai tradisional. Proses pengambilannya dilakukan dengan sebuah ritual yang disebut dengan Meudayang. Sebelum madu diambil, pawang harus melantunkan syair-syair berisi sapaan terhadap lebah. ${ }^{1}$

Sistem pengemasan madu di desa ini masih menggunakan botol minuman segar, jarken, dan kemasan lainnya untuk membungkus madu dan dipasarkan ke luar. Keadaan demikian dapat mengurangi kepercayaan petani terhadap madu Buloh Seuma. Permasalahan tersebut membuat sistem promosi di desa Buloh Seuma terhambat, penggunaan produksi membuat kualitas madu bisa tercoreng, idealnya para petani madu dengan kualitas yang bagus bisa menerbitkan dan memasarkan madu dengan memakai lebel resmi dan tempat yang dibuat secara khusus.

Pertanian hendaknya tidak diartikan hanya untuk meningkatkan produksi tanaman pangan dan perkebunan saja, akan tetapi harus meliputi semua kegiatan usaha dalam meningkatkan kesejahteraan, derajat dan martabat kaum tani Indonesia. Salah satu kegiatan usaha yang juga diperlukan mendapatkan perhatian dalam hal ini adalah ternak lebah madu.

Pertimbangan untuk beternak lebah madu ini selain menguntungkan, juga memberikan dampak positif dalam hal penyerapan tenaga kerja. pertanian merupakan sektor yang sangat penting dalam pembangunan perekonomian masyarakat. ${ }^{2}$ Lebah

\footnotetext{
1 Aceh tourism, Madu dan kearifan lokal buloh seuma, http://www.acehtourism.info/id/madu- dan-kearifan-lokal-buloh-seuma/, Di akses, 26 Desember 2017, pukul 16: 20.

${ }^{2}$ Eka Pratiwi, strategi pemasaran industri madu,/ tugas akhir, (Batang, 2010), h. 5
} 
digembalakan secara berpindah-pindah mengikuti musim pembungaan tanaman. ${ }^{3}$

Menarik untuk melihat bagaimana khazanah hukum tentang promosi produk dalam syariat Islam, yaitu dari produk fikih yang tidak luput dari pemahaman al-Qur'an dan hadis sebagai sumber pengambilan hukumnya. Sehingga diharapkan bahwa khazanah Islam dalam hal ini dapat dijadikan sebagai pedoman khususnya mengenai cara mempromosikan sebuah produk yang dibenarkan oleh ajaran Islam. Di samping itu, permasalahan mengenai hukum promosi madu dalam perspektif Islam menarik untuk dikaji lantaran fenomena permasalahan yang dihadapi konsumen semakin berkembang, sementara masih belum didapati ketentuan atau kajian khusus yang memabahas mengenai promosi produk berdasarkan syariat Islam.

Adapun promosi madu yang sedang dilakukan sekarang ini belum memaksimalkan para konsumen untuk membeli madu. Atas dasar tersebut penelitian ini penting dilakukan untuk mengetahui bagaimana sistem promosi madu gampong Buloh Seuma Aceh Selatan. Berpijak dari latar belakang tersebut maka penulis melakukan penelitian dengan judul: "Sistem Promosi Madu Gampong Buloh Seuma Aceh Selatan”.

\section{Rumusan Masalah}

Berdasarkan latar belakang di atas maka yang menjadi permasalahan dalam penelitian ini ialah sebagai berikut:

1. Bagaimana sistem promosi dalam perspektif hukum Islam yang digunakan petani madu Gampong Buloh Seuma Aceh Selatan?

2. Kendala apa yang dihadapi petani madu Gampong Buloh Seuma Aceh Selatan dalam proses promosi madu dalam perspektif hukum Islam?

${ }^{3}$ Asmanah Widiarti dan kundati, budidaya lebah madu, / tugas akhir, (jawa tengah, 2012), h. 4 


\section{Tujuan Penelitian}

Berdasarkan rumusan masalah maka yang menjadi tujuan penelitian ialah sebagai berikut:

1. Untuk mengetahui bagaimana sistem promosi dalam perspektif hukum Islam yang digunakan petani madu Gampong Buloh Seuma Aceh Selatan.

2. Untuk mengetahui bagaimana kendala apa yang dihadapi petani madu Gampong Buloh Seuma Aceh Selatan dalam proses promosi madu dalam perspektif hukum Islam.

\section{Manfaat Penelitian}

1. Secara teoritis, peneliti dapat menerapkan ilmu yang diperoleh selama menjadi meneliti yang berkaitan dengan komunikasi nonverbal.

2. Secara praktis, penelitian ini diharapkan dapat menambah khasanah dan literatur keilmuan bagi para peneliti sistem promosi berikutnya, khususnya dalam system promosi madu.

\section{Metodologi Penelitian}

Dalam penulisan suatu karya ilmiah, metode penelitian sangatlah menentukan untuk eferktif dan sistematisnya sebuah penelitian. Berdasarkan permasalahan yang diangkat, penelitian ini menggunakan metode kualitatif untuk mendapatkan hasil penelitian yang mendekati dengan keadaan yang sebenarnya ada dilapangan.

Qualitative Research adalah jenis penelitian yang menghasilkan penemuan- penemuan yang tidak dapat dicapai dengan menggunakan prosedur-prosedur statistic atau dengan cara kuantifikasi lainnya. Penelitian kualitatif dapat digunakan untuk meneliti kehidupan masyarakat, sejarah, tingkah laku, fungsionalisasi organisasi, gerakan sosial atau hubungan kekarabatan. ${ }^{4}$

Sedangkan ditinjau dari sifatnya, penelitian ini tergolong pada penelitian deskriptif, penelitian yang diuraikan dengan kata-kata

${ }^{4}$ Basrowi dan Suwandi, Memahami Penelitian Kualitatif, (Jakarta: PT Rineka Cipta, 2008), h. 1. 
menurut pendapat informan, apa adanya sesuai dengan pertanyaan penelitiannya, kemudian dianalisis dengan kata- kata apa yang melatar belakangi responden berperilaku (berfikir, berperasaan, dan bertindak). ${ }^{5}$ Jenis penelitian ini bertujuan membuat deskripsi secara sistematis, factual dan akurat tentang fakta-fakta dan sifat-sifat populasi atau objek tertentu. Serta menggambarkan realitas yang sedang terjadi tanpa menjelaskan hubungan antar variabel. ${ }^{6}$

\section{B. Pembahasan}

\section{Pengertian Sistem Promosi}

Sistem menurut Kamus Besar Bahasa Indonesia adalah seperangkat unsur yang teratur dan saling berkaitan sehingga membentuk suatu totalitas. ${ }^{7}$ Adapun pengertian sistem secara istilah sehimpunan bahagian atau komponen yang saling berhubungan secara sistematis dan merupakan satu keseluruhan. Sistem adalah suatu jaringan kerja dari prosedur-prosedur yang saling berhubungan, berkumpul bersama- sama untuk melakukan sesuatu kegiatan atau untuk menyelesaikan suatu sasaran yang tertentu. ${ }^{8}$

Promosi adalah suatu komunikasi pemasaran yang berusaha menyebarkan informasi, mempengaruhi atau membujuk dan mengingatkan pasar sasaran atas perusahaan dan produknya agar bersedia menerima, memiliki kualitas tinggi serta dapat memenuhi kebutuhan konsumen membeli, dan loyal pada produk yang ditawarkan memperhatikan perusahaan yang bersangkutan. ${ }^{9}$

Dalam melakukan promosi agar dapat efektif perlu adanya bauran promosi, yaitu kombinasi yang optimal bagi berbagai jenis

\footnotetext{
${ }^{5}$ Husaini Usman dan Purnomo Setiady Akbar, Metodologi Penelitian Sosial, (Jakarta: Bumi Aksara, 2008), h. 30.

${ }^{6}$ Rachmat Krisyantono, Teknik Praktis Riset Komunikasi, (Jakarta: Kencana Prenada Media Group, 2006), h. 67.

${ }^{7}$ Departemen Pendidikan dan Kebudayaan, Kamus Besar Bahasa Indonesia, Cet. III, Balai Pustaka, Jakarta 1990, h. 849.

${ }^{8}$ Yulistia, M. Ikhsan Indriansyah, Sistem Informasi Penjualan Berbasis Web dan Sms Gateway pada Cv Tricita Computer, STMIK GIMPD, h.2.

${ }^{9}$ Dwi Purwanto, Strategi Promosi pada PT. Madu Baru, (Yogyakarta, Tugas Akhir, 2015), h. 1.
} 
kegiatan atau pemilihan jenis kegiatan promosi yang paling efektif dalam meningkatkan penjualan. Ada lima jenis kegiatan promosi, antara lain:

a. Periklanan; yaitu bentuk promosi non personal dengan menggunakan berbagai media yang ditujukan untuk merangsang pembelian.

b. Penjualan tatap muka; yaitu bentuk promosi secara personal dengan presentasi lisan dalam suatu percakapan dengan calon pembeli yang ditujukan untuk merangsang pembelian.

c. Publisitas; yaitu suatu bentuk promosi non personal mengenai pelayanan atau kesatuan usaha tertentu dengan jalan mengulas informasi/berita tentangnya (pada umumnya bersifat ilmiah).

d. Promosi penjualan; yaitu suatu bentuk promosi diluar ketiga bentuk di atas yang ditujukan untuk merangsang pembelian.

e. Pemasaran langsung; yaitu suatu bentuk penjualan perorangan secara langsung ditujukan untuk mempengaruhi pembelian konsumen.

Promosi penjualan yang dilakukan oleh penjual dapat dikelompokkan berdasarkan tujuan yang ingin dicapai. Pengelompokan tersebut sebagai berikut:

a. Promosi yang bertujuan untuk mendorong atau merangsang pelanggan untuk membeli.

b. Promosi penjualan yang bertujuan merangsang atau mendorong pedagang grosir, pengeceran, eksportir dan importir untuk memperdagangkan barang atau jasa dari sponsor.

c. Promosi penjualan yang berujuan untuk memotivasi armada penjualan.

d. Promosi penjualan yang bertujuan untuk memperoleh pelanggan baru, mempertahankan kontrak hubungan dengan pelanggan, memperkenalkan produk baru, menjual lebih banyak kepada pelanggan lama, dan mendidik pelanggan.

\section{Tujuan dan Fungsi Promosi}

Promosi penjualan dimaksudkan sebagai suatu cara untuk menarik minat konsumen sehingga dapat menimbulkan perhatian 
tentang barang tersebut. Promosi penjualan adalah insentif yang dirancang untuk mendorong pembelian atau penjualan sebuah produk (biasanya untuk jangka pendek) yaitu seperti kupon, sayembara, perlombaan, sampel produk, dan lain-lain. Promosi penjualan merupakan kegiatan yang penting dalam pemasaran suatu produk yang dilakukan oleh sebagian besar organisasi termasuk produsen, pengecer dan organisasi lainnya. Adapun promosi penjualan tersebut juga merupakan unsur kunci dalam kampanye pemasaran.

\section{Metode dalam Sistem Promosi}

Komunikasi dengan konsumen adalah penting untuk merangsang, mendorong penjualan produk dan memelihara image toko. Untuk menentukan cara terbaik menjual produk, kebutuhan pokok adalah tentang sifat perpaduan promosi yang mungkin paling efektif.

Khususnya bagaimana iklan, kewiraniagaan, promosi konsumen (perlombaan, hadiah, dan penawaran konbinasi), dan kegiatan promosi dealer dapat digabungkan menjadi suatu perpaduan penjualan yang efektif.

\section{Hukum Promosi menurut Hukum Islam}

Istilah promosi dalam Islam dikenal dengan sebutan at-tarwij Secara bahasa at-tarwij diartikan sebagai, "segala sesuatu yang mendorong atau menarik minat (membujuk) orang lain untuk membeli." 10

Dalam pengertian secara terminologis, Khalid bin Abd Allah mengemukakan bahwa untuk memberi batasan pengertian al-hawafiz al-muraghghibah fi al-shaira', tentu harus merujuk pada buku-buku pemasaran (marketing) yang mengulas tentang permasalahan ini dan menjadikannya sebagai pokok bahasan. Menurut Khalid, dengan merujuk dari buku-buku tersebut diketahui bahwa istilah yang digunakan untuk menunjukkan pengertian sesuatu yang mendorong

${ }^{10}$ Khalid bin Abd Allah al-Muslih, al-Hawafiz al-Tijariyah, (t.t.p: t.p., t.t.), h. 9. 
dan membujuk orang lain untuk membeli disebut dengan istilah promotion (promosi).

Promosi ini mempunyai dua makna: makna umum dan makna khusus. Makna umum promosi adalah segala perbuatan yang dilakukan oleh shirkah (perusahaan atau produsen) untuk menambah hasil penjualan. Sedangkan arti promosi secara khusus adalah hubungan komunikatif penjual atau produsen kepada para pembeli dengan maksud untuk memberi tahu mereka, membujuk dan mendorong mereka untuk membeli.

Dari pengertian ini Khalid bin Abd Allah menyimpulkan bahwa istilah promosi secara umum mempunyai kedekatan dengan al-hawafiz al-muraghghibah fi al-shira'. Berbeda dengan pengertian promosi secara khusus yang menurut Khalid, biasanya hanya mencakup segala tindakan sebelum terjadinya transaksi jual beli sedangkan setelah terjadinya transaksi jual beli seperti perjanjian daman atau garansi serta layanan-layanan yang lain tidak termasuk dalam pengertian promosi. ${ }^{11}$

Penulis dalam hal ini sependapat dengan pernyataan Khalid yang menyebutkan kedekatan makna antara al-hawafiz almuraghghibah fi al-shira' dengan pengertian promosi secara umum. Akan tetapi dalam pengertian khusus penulis tidak sependapat, lantaran dewasa ini, promosi juga mencakup tindakan atau layananlayanan setelah terjadinya akad jual beli, seperti halnya garansi yang juga menjadi bagian dari kiat-kiat promosi. ${ }^{12}$ Begitu juga pemberian hadiah dengan penarikan hadiah pada waktu tertentu setelah terjadinya akad jual beli juga termasuk bagian dari promosi. ${ }^{13}$

Dengan demikian, kesimpulan pengertian Khalid bin Abd Allah mengenai al-hawa fiz al-muraghghibah fi al-shira' adalah segala sesuatu yang dilakukan oleh penjual atau produsen, baik terdiri dari perbuatan-perbuatan untuk memperkenalkan barang dagangan (komoditi) atau layanan-layanan yang mendorong dan menarik minat

${ }^{11}$ Ibid., h. 10.

${ }^{12}$ Tung Desem Waringin, Marketing Revolution (Jakarta: Gramedia Pustaka Utama, 2013), h. 6.

${ }^{13}$ Frank Jefkins, Periklanan, Edisi Ketiga (Jakarta: Erlangga, 1997), h. 154-156. 
orang lain untuk memiliki dan membelinya, baik aktivitas itu sebelum akad jual beli atau sesudahnya.

Bentuk-bentuk al-hawafiz al-muraghghibah fi al-shira' (promosi) sangat beragam karena itu pembahasan dalam artikel ini dibatasi dalam bahasan periklanan dan promosi penjualan, seperti hadiah, perlombaan atau sayembara dan lain-lain.

\section{Hukum Promosi Penjualan}

Sebagaimana diketahui sebelumnya bahwa prinsip dalam muamalah adalah boleh selama tidak ada dalil yang melarangnya. Atas dasar itu maka hukum promosi penjualan pada asalnya adalah boleh, selama dilakukan menurut cara yang dibenarkan oleh syariat, tidak menimbulkan bahaya dan gharar.

Dalam pembahasan ini, akan dikaji mengenai bentuk-bentuk promosi penjualan, apakah suatu promosi penjualan dapat dibenarkan secara syar'i atau tidak. Untuk itu, pembahasan akan dirinci sebagai berikut: pertama, promosi dengan sampel. Sebagaimana diketahui bahwa sampel merupakan tawaran barang percobaan atau gratis yang diberikan kepada konsumen. Dalam istilah fikih jual beli dengan sampel ini dikenal dengan sebutan al-bai' bi al-namudhaj (jual beli dengan contoh atau sampel). Dalam jual beli semacam ini, hukum Islam menentukan bahwa sebuah komoditi harus sesuai dengan sampel yang diberikan. Hal ini didasarkan bahwa hukum Islam mensyaratkan adanya objek transaksi harus diketahui oleh kedua belah pihak yang melakukan transaksi, agar terhindar dari unsur jahalah (ketidakjelasan objek akad), yang nantinya dapat mendatangkan gharar dan persengketaan antara kedua belah pihak yang melakukan akad. Syarat ini merupakan syarat yang disepakati oleh para ulama fikih. ${ }^{14}$

Dalam hal ini, 'Ali Haidar mengemukakan dalam Kitab Sharh Majallat pasal 324 bahwa:

${ }^{14}$ Wahbah al-Zuhaili, al-Fiqh al-Islami wa Adillatuhu (Suriah: Dar al-Fikr bi Damsyiq, 2002), h. 725 dan 260. 
Barang-barang yang dijual dengan menggunakan contoh atau sampel, cukup dilakukan dengan melihat contohnya saja." 15

Atas dasar itu dapat dikatakan bahwa jual beli dengan sampel ini adalah sah, dengan syarat, sampel tersebut sesuai dengan objek transaksi. Jika kemudian konsumen melihat objek akad tidak sesuai dengan sampel yang diberikan maka konsumen berhak untuk melakukan khiyar, sebagaimana disebutkan dalam Sharh Majallat pasal 320: "Barang siapa yang membeli sesuatu yang belum ia lihat maka ia berhak untuk khiyar hingga ia melihatnya. Selanjutnya, setelah ia melihat, ia boleh menerimanya atau membatalkan akad jual beli. Khiyar semacam ini disebut dengan khiyar ru'yah. ${ }^{16}$

Arti melihat objek transaksi seperti yang dimaksud di atas, tidak hanya menggunakan penglihatan mata saja, tetapi juga dapat dilakukan dengan indra-indra yang lain untuk mengetahui keadaan yang dimaksudkan. Misalnya dengan mencium bau-bau dalam komoditas yang mengandung bau seperti parfum, mencicipi makanan, menyentuh objek akad dan lain sebagainya. ${ }^{17}$

Kedua, demonstrasi-demonstrasi dalam toko. Telah disebutkan sebelumnya bahwa kegiatan ini merupakan salah satu bentuk promosi dengan mendemonstrasikan penggunaan produk, atau menawarkan sampel dan sekaligus menjual produk yang didemonstrasikan atau sekadar memberikan informasi. Dilihat dari bentuknya kegiatan demonstrasi ini dilakukan dengan dua cara, yaitu dengan memperagakan sebuah produk atau menawarkan sampel dan dengan memberikan informasi mengenai kriteria produk. Dalam hukum Islam kedua bentuk tersebut dikenal dengan istilah al-bai' bi al-'ainah dan al-bai' bi al-sifat.

Istilah lain yang digunakan sebagai sinonim dari al-bai' bi al'ainah dan al-bai' bi al-sifat adalah al-bai' bi al-namudhaj (jual beli dengan sampel) yang telah diuraikan hukumnya di atas. Dengan

15 'Ali Haidar, Durar al-Hukkam Syarh Majallat al-Ahkam (Beirut: Dar al-Kutub al'Alamiyyah, t.t.), h. 273.

${ }^{16}$ Ibid., h. 269.

${ }^{17}$ Wahbah al-Zuhaili, al-Fiqh al-Islami, h. 262. 
demikian hukum demonstrasi ini adalah boleh, dengan syarat barang yang diperagakan atau didemontrasikan serta informasi yang diberikan sesuai dengan barang yang dijual belikan. Di lain itu, si pembeli juga berhak atas khiyar, jika ia melihat produk yang menjadi objek akad sebenarnya. ${ }^{18}$

Ketiga, potongan harga atau diskon (paket harga, kemasankemasan jumbo, kupon dan premi). Dalam istilah marketing, potongan harga diartikan sebagai harga rendah yang diberikan oleh penjual kepada pembeli atas suatu komoditi atau jasa tertentu, untuk mendorong manusia melakukan pembelian atau mempertahankan mereka melakukan aktivitas jual beli dengan penjual. ${ }^{19}$ Jika kita perhatikan definisi di atas maka dapat kita ketahui beberapa bentuk promosi penjualan yang masuk dalam kategori potongan harga ini, yaitu paket harga, kemasan-kemasan ukuran jumbo atau ganda, kupon dan premi.

Istilah potongan harga atau diskon ini memang belum dikenal di kalangan fuqaha dalam kitab-kitab mereka. Akan tetapi istilah yang dikenal mereka untuk menunjuk pengertian potongan harga atau diskon adalah al-hatt min al-thaman atau al-naqs min al-thaman (penurunan harga atau pengurangan harga). ${ }^{20}$

Keempat, hadiah dalam kemasan. Telah disebutkan sebelumnya bahwa hadiah adalah salah satu bentuk dari hibah, yaitu memindahkan hak milik tanpa adanya pengganti. Hibah yang dimaksudkan untuk Allah disebut sedekah, sedangkan hibah untuk memuliakan seseorang, menambah kecintaan, sebagai imbalan atau insentif (mukāfa'ah) dan lain sebagainya maka hibah semacam ini disebut hadiah. ${ }^{21}$ Hukum hadiah pada asalnya adalah dianjurkan (sunnah) dan karena itu hadiah ini termasuk dari akad tabarru' (ibadah).

Kelima, memberi hadiah, tapi mendapat keuntungan dari penjualan hadiah. Taruhlah seorang penjual emas, memberitahukan

\footnotetext{
${ }^{18}$ Khalid bin Abd Allah al-Muslih,al-Hawafi,h. 184.

${ }^{19}$ Ibid., h. 34.

${ }^{20}$ al-Maqdisi,al-Mughni (Beirut: Dar al-Kutub al-Ilmiyyah, t.t.) h. 265.

${ }^{21}$ Tung Desem Waringin, Marketing Revolution, h. 20-21.
} 
kepada konsumen bahwa jika membeli 10 gram emas dapat kaos gratis. Akan tetapi jika beli 5 gram bisa dapat kaos gratis cukup bayar Rp. 2.000,00 (harga kaos jenis tersebut dipasaran saat itu Rp. 4.000,00). Penjual karena membelinya secara grosir dari pabriknya, harga setiap kaos adalah Rp. 1.700,00. Praktik semacam ini akan mendapat untung tiga kali lipat.

Untung dari penjualan emas, dari hadiah kaos dan ketika kaos tersebut dipakai, hal sama dengan mempromosikan tokonya. Jadi yang terjadi adalah seorang membeli emas 5 gram dengan menambah $\mathrm{Rp}$. 2.000,00 untuk mendapatkan kaos sehingga toko sebagai pihak yang memberi hadiah, bahkan mendapat keuntungan berlipat, yaitu keuntungan Rp. 300,00 karena harga setiap kaos dibeli seharga Rp.1.700,00, keuntungan dapat menarik pelanggan dan jika kaos itu dipakai itu juga berarti ia mendapat keuntungan promosi secara gratis. ${ }^{22}$

Berdasarkan uraian di atas maka kita akan mendapatkan ada dua permasalahan hukum; a) penjual yang mengatakan barang siapa membeli emas 10 gram, ia akan dapat gratis, b) penjual yang mengatakan barang siapa yang membeli emas 5 gram bisa dapat kaos gratis cukup bayar Rp. 2.000,00 (harga kaos jenis tersebut dipasaran saat itu Rp. 4.000,00. sedangkan penjual, membelinya secara grosir dari pabriknya, harga setiap kaos adalah Rp. 1.700,00).

Dalam hal ini, sebenarnya terdapat dua jual beli dalam satu akad (bai'atayn fi bai'ah), yaitu jual beli emas 5 gram dan jual beli kaos. Jika dianggap keduanya adalah jual beli secara terpisah dalam arti ada akad jual beli emas dan ada akad jual beli kaos maka akad yang kedua terdapat jahalah (ketidakjelasan) dalam akad. Hal ini karena ungkapan "dapat kaos gratis dengan bayar Rp. 2.000,00”, menimbulkan persepsi antara hadiah dan jual beli, atau bisa jadi pembeli menganggapnya sebagai hadiah meskipun pada dasarnya adalah jual beli dan ini mengarah kepada penipuan atau gharar.

\footnotetext{
${ }^{22}$ Atiah Saqar,Fatawa al-Azhar,Juz 10 (Kairo: Dar al-Ifta’ al-Misriyyah, 1997), h.
} 99. 
Keenam, undian atau sayembara. Mengenai undian atau sayembara ini, ada dua pendapat yaitu ada yang memperbolehkan dan ada yang melarang untuk lebih jelasnya adalah sebagai berikut; 1) Pendapat yang memperbolehkan. Termasuk dalam kelompok pendapat yang memperbolehkan undian adalah jumhur ulama dan Yusuf Qardawi. Dalam Fata wa al-Azhar,'Atiah Saqar mengemukakan mengenai pembagian hadiah dengan cara undian kepada seseorang yang melakukan suatu perbuatan dan dianggap berhak untuk mendapatkan hadiah tersebut. Menurutnya, undian adalah boleh secara syar'i tidak diharamkan dan sudah dikenal mulai zaman dahulu. 2) Pendapat yang melarang. Berbeda dengan pendapat di atas (yang membolehkan undian) yaitu pendapat Abu Hanifah dan pengikutnya. Menurut mereka, undian adalah serupa dengan al-azlam (mengundi nasib dengan panah) yang dilarang oleh Allah. Akan tetapi Ibn alMundhir, meriwayatkan dari Abu Hanifah bahwa ia (Abu Hanifah) membolehkannya dan bahkan berkata bahwa analogi (qiyas) terhadap undian yang disamakan dengan al-azlam, tidak dapat dibenarkan. Oleh karena itu ia meninggalkan qiyas tersebut dan memilih ketentuan hadis dan al-Qur'an yang membolehkannya. ${ }^{23}$

Khalid bin Abd Allah al-Muslih, dalam hal ini mengemukakan bahwa bentuk promosi semacam ini adalah haram didasarkan pada alasan berikut. Pertama, jenis hadiah semacam ini akan mendorong orang untuk membeli barang yang tidak diperlukan sehingga termasuk dalam kategori pemborosan (tabdhir) dan berlebih-lebihan (israf) yang dilarang oleh Allah Swt sebagaimana firmannya dalam QS. al-An'am: 141: Artinya:"....dan janganlah kamu berlebih-lebihan, sesungguhnya Allah tidak menyukai orang yang berlebih-lebihan." Kedua, bentuk hadiah semacam ini mengandung judi karena terdapat unsur untung-rugi.

Dari kedua pendapat tersebut, baik dari pendapat yang membolehkan dan pendapat yang melarang, jika digabungkan 38 dapat ditarik kesimpulan bahwa hukum hadiah dengan undian atau

${ }^{23}$ Yaitu dengan menggunakan konsep al-jam'u wa al-taufiq(mengumpulkan dua dalil yang bertentangan, kemudian mengkompromokannya). Hal ini didasarkan karena mengamalkan kedua dalil itu lebih baik daripada meninggalkan salah satu di antaranya. Nasrun Haroen, Ushul Fiqh 1 (Jakarta: Logos Wacana Ilmu, 1997), h. 178-179. 
sayembara ini adalah boleh, jika memang si pembeli mempunyai kebutuhan terhadap barang yang dibeli bukan karena motivasi hadiah semata. Sehingga dalam hal ini akan terhindar dari unsur judi, pemborosan dan berlebih-lebihan. Sebaliknya, jika karena motivasi hadiah semata maka hukumnya adalah haram karena termasuk membeli barang atau produk yang tidak dibutuhkan dan mengarah pada judi.

\section{Pembahasan Hasil Penelitian}

Madu adalah salah satu mata pencaharian penduduk pemukiman Buloh Seuma. Di mana dengan madu tersebut penduduk Buloh Seuma dapat menghasilkan rezeki untuk kehidupan sehari-hari. Usaha ternak lebah madu merupakan usaha pengembangan dan penjualan produk hasil ternak lebah madu. Usaha tersebut dilakukan untuk memenuhi kebutuhan produk madu yang terus meningkat. Besarnya permintaan terhadap madu belum dapat diimbangi oleh kemampuan industri perlebahan dalam meningkatkan produksi madu, sehingga untuk mengatasi kondisi tersebut maka pengembangan usaha lebah madu perlu dilakukan. Petani usaha ternak lebah madu tidak memiliki pengetahuan tentang pemeliharaan dan perawatan ternak lebah madu yang tepat. Padahal jika para petani ingin hasil madunya memiliki kualitas dan kuantitas yang baik para petani harus melakukan proses-proses pemeliharaan yang tepat seperti melakukan sanitasi, memperhatikan cuaca (suhu), kebersihan sarang (stup) dan juga melakukan pengontrolan penyakit terhadap ternak lebah madu.

Ternak lebah madu ini sudah lama dilakukan oleh masyarakat tradisional di Indonesia. Kegiatan ternak ini umumnya dilakukan oleh masyarakat di pelosok pedesaan, terutama berdampingan dengan usaha tani masyarakat. Pada saat ini, kegiatan ternak lebah semakin meningkat, hal ini sejalan dengan makin meningkatnya semangat hidup sehat setiap orang salah satunya dengan mengkonsumsi madu. Terdapat beragam jenis lebah yang bisa diternakkan diantaranya spesies lebah hutan (Apis mellifera), spesies lebah ternak Asia (Apis cerana/Apis indica). Dari spesies tersebut spesies Apis mellifera merupakan spesies terbaik dalam menghasilkan madu. Spesies Apis 
mellifera sangat rakus terhadap makanan sehingga perlu perawatan dan pemindahan lokasi ternak bila masa bunga habis. Lebah madu Apis mellifera biasanya diternakkan oleh pengusaha lebah.

Madu merupakan mata pencaharian pemukiman Buloh Seuma, di Buloh Seuma terdapat beberapa pohon untuk persinggahan lebah sebagai pembuatan sarang madu. Adapun dalam pengambilan madu harus orang-orang tertentu yang dapat mengambil madu tersebut, karena dalam pengambilan madu tersebut harus ada orang- orang yang ahli atau disebut pawang madu.

Madu datangnya bermusim yaitu pada musim timur dan musim barat. Pengambilan madu dilakukan dalam tempo 1 tahun 2 kali atau 6 bulan 1 kali. Penentuan waktu adanya madu dilihat dari hari pertama madu tersebut menetap dipohon sampai hari ke 30. Cara mengambil madu yaitu disesuaikan dengan umur madu dari hari pertama madu itu menetap, dilakukannya pada waktu malam pukul 00.00 wib s/d 04.00 wib, dan dilihat juga pada bulannya yaitu pada bulan yang gelap, karena pengambilan madu tersebut tidak dibolehkan dalam keadaan terang.

Dalam promosi lebah madu dilakukan secara tatap muka dengan masyarakat. Masyarakat bisa langsung melihat produknya, karena petani di desa ini masih sangat awam dalam pemahamannya mengenai internet jadi mereka tidak mengetahui bagaimana cara untuk mempromosikan madu ini ke masyarakat jika menggunakan teknologi sekarang. Menurut hukum Islam pun promosi dengan cara yang dilakukan oleh petani ini lebih efektif dibandingkan menggunakan promosi secara online. Kenapa begitu? Sebab masyarakat bisa melihat langsung kualitas madu yang diperdagangkan itu seperti apa.

Sebagaimana diketahui sebelumnya bahwa prinsip dalam muamalah adalah boleh selama tidak ada dalil yang melarangnya. Atas dasar itu maka hukum promosi penjualan pada asalnya adalah boleh, selama dilakukan menurut cara yang dibenarkan oleh syariat, tidak menimbulkan bahaya dan gharar.

Menurut penelitian mengenai bentuk-bentuk promosi penjualan, apakah suatu promosi penjualan dapat dibenarkan secara 
syar'i atau tidak. Iya, promosi lebah madu ini dibenarkan secara syar'i, karena promosinya dengan sampel. Sebagaimana diketahui bahwa sampel merupakan tawaran barang percobaan atau gratis yang diberikan kepada konsumen. Dalam istilah fikih jual beli dengan sampel ini dikenal dengan sebutan al-bai' bi al-namudhaj (jual beli dengan contoh atau sampel). Dalam jual beli semacam ini, hukum Islam menentukan bahwa sebuah komoditi harus sesuai dengan sampel yang diberikan. Hal ini didasarkan bahwa hukum Islam mensyaratkan adanya objek transaksi harus diketahui oleh kedua belah pihak yang melakukan transaksi, agar terhindar dari unsur jahalah (ketidakjelasan objek akad), yang nantinya dapat mendatangkan gharar dan persengketaan antara kedua belah pihak yang melakukan akad. Syarat ini merupakan syarat yang disepakati oleh para ulama fikih.

Jadi para petani di Buloh Seuma sudah melakukan proses jual beli dengan apa yang diajarkan dalam Islam, yaitu dengan secara jelas memperlihatkan sampel madunya terhadap pembeli. Serta banyak pembeli yang puas akan proses marketing tradisional tersebut. Petani madu Buloh Seuma sudah mengikuti kriteria-kriteria yang dibutuhkan guna menjadi seorang marketer syariah yang profesional. Diantaranya: amanah, menjaga kualitas, profesianal, inovatif, estetika dalam diri dan hasil kerja, fair dan memiliki ahlaqul karimah. Kemudian, memahami alat-alat analisis dan program komunikasi pemasaran, jenis-jenis transaksi sesuai syariah, dan yang terpenting dalam dirinya harus terpatri bahwa apakah pasarnya muslim atau bukan, pelaksanaan manajemen pemasarannya harus Islami.

Adapun kelebihan dan kekurangan dari proses jual beli madu di Buloh Seuma secara marketing Islam adalah:

a. Kelebihannya, Buloh Seuma dikenal dengan hutan lindung dimana hutan tersebut dijadikan sebagai mata pencaharian petani yang ada di pemukiman Buloh Seuma. Dengan adanya hutan lindung tersebut maka para petani dapat menjadikan pohon-pohon besar yang ada dalam hutan sebagai pohon pembawa rezeki yaitu karena adanya madu yang akan menetap di pohon tersebut. Maka dengan cara tersebut para petani tahu kualitas madunya, yang mana itu 
bisa langsung dijadikan sampel untuk masyarakat buloh Seuma. Dalam proses marketing Islam ini terlihat kejujuran dalam jualbeli, sebagaimana dalam Islam, kebebasan manusia didasarkan atas nilai-nilai tauhid. Nilai tauhid inilah yang membuat petani Buloh Seuma memiliki keberanian dan kepercayaan. Dalam sistem marketing Islam mensyaratkan setiap individu memiliki kebebasan dalam mengutarakan pikirannya, yang mana itu juga dilakukan oleh petani madu yang berjualan secara tatap muka, bebas memberikan informasi mengenai madu yang dijualnya ke pembeli. Kebebasan inilah akan mampu mengoptimalkan kemampuan manusia dalam bertahan hidup. Selain itu, setiap individu juga bebas dalam membuat keputusan yang berhubungan dengan ekonominya tanpa didasari paksaan dari siapapun.

b. Kekurangannya, banyaknya pengangguran yang terjadi bukanlah sekedar didasari oleh kemalasan individunya. Namun, saat ini fenomena pengangguran lebih disebabkan karena pemahaman masyarakat mengenai makna dan jenis pendapatan atau penghasilan yang belum tepat. Ekonomi syariah masih belum dapat membantu ekonomi kerakyatan, apalagi seperti yang dilakukan petani Buloh Seuma. Di mana proses marketing Islamnya masih dalam bentuk tradisional, itu disebabkan tidak adanya pemahaman masyarakat mengenai teknologi.

Adapun di sini rekomendasi dari peneliti buat petani Buloh Seuma yaitu pemerintah Aceh Selatan bisa membuat pelatihan untuk masyarakat mengenai promosi lebah madu, yang mana promosi itu dikemas dalam proses marketing Islam. Agar masyarakat Buloh Seuma memahami dengan mendalam marketing Islam itu seperti apa. Dan proses ini juga harus ada pengajaran mengenai penjualan online bagi para petani, yang mana lebah madu bisa dikenal oleh banyak khalayak, tidak hanya dalam zona perkampungan Buloh Seuma saja. 


\section{Penutup}

Promosi merupakan salah satu cara yang dibutuhkan perusahaan dalam meningkatkan volume penjualan. Oleh karena itu kegiatan promosi ini harus dapat dilakukan sejalan dengan rencana pemasaran serta diarahkan dan dikendalikan dengan baik sehingga promosi tersebut benar-benar dapat memberikan kontribusi yang tinggi dalam upaya meningkatkan volume penjualan.

Berdasarkan hasil penelitian ini dapat disimpulkan bahwa sistem promosi madu pada Gampong Buloh Seuma masih menggunakan sistem promosi tradisional artinya belum menggunakan sumber komersial (iklan, wiraniaga, penyalur, kemasan, pajangan di toko), jadi pemasaran yang dilakukan hanya menyampaikan informasi melalui mulut ke mulut. Adapun sistem organisasi terpusat sering digunakan karena perusahaan tidak memiliki banyak jenis dan merek produk untuk diiklankan atau di promosikan. Sedangkan kendala petani dalam mempromosikan madu yaitu belum adanya label asli atau merek yang dapat dipercayai oleh para konsumen luar.

Sudah tidak menjadi rahasia lagi bahwasanya iklan dan promosi adalah sarana yang dibutuhkan oleh para penjual atau produsen terutama ketika kita melihat realitas pasar perdagangan masa kini yang menampilkan sangat banyak sekali berbagai macam produk baik barang maupun jasa. Dan yang menjadi kekurangan dalam mempromosikan madu ini adalah masih secara tradisional namun tidak lepas mengikuti aturan marketing Islam.

Adapun dalam persepektif hukum Islam, sistem promosi dapat dilakukan atau disebut dengan mubah (dibolehkan), terutama dalam promosi terdapat usaha untuk menginformasikan kepada konsumen akan detail barang maupun yang akan dibeli. Serta hal tersebut juga ada kekurangan dan kelebihannya terutama dalam mempromosikan madu di Buloh Seuma secara marketing Islam. 


\section{Daftar Pustaka}

Aceh tourism, Madu dan kearifan lokal buloh seuma,http://www.acehtourism.info/id/madu- dan-kearifanlokal-buloh-seuma/, Di akses, 26 Desember 2017, pukul 16: 20.

Asmanah Widiarti dan kundati, budidaya lebah madu, / tugas akhir, jawa tengah, 2012.

'Ali Haidar, Durar al-Hukkam Syarh Majallat al-Ahkam Beirut: Dar alKutub al-'Alamiyyah, t.t.

Al-Maqdisi, al-Mughni, Beirut: Dar al-Kutub al-Ilmiyyah, t.t.

Atiah Saqar,Fatawa al-Azhar,Juz 10, Kairo: Dar al-Ifta’ al-Misriyyah, 1997.

Basrowi dan Suwandi, Memahami Penelitian Kualitatif, Jakarta: PT Rineka Cipta, 2008.

Departemen Pendidikan dan Kebudayaan, Kamus Besar Bahasa Indonesia, Cet. III, Balai Pustaka, Jakarta 1990.

Dwi Purwanto, Strategi Promosi pada PT. Madu Baru, Yogyakarta, Tugas Akhir, 2015.

Eka Pratiwi, strategi pemasaran industri madu,/ tugas akhir, Batang, 2010.

Frank Jefkins, Periklanan, Edisi Ketiga, Jakarta: Erlangga, 1997.

Husaini Usman dan Purnomo Setiady Akbar, Metodologi Penelitian Sosial, Jakarta: Bumi Aksara, 2008.

Khalid bin Abd Allah al-Muslih,al-Hawafiz al-Tijariyah, t.t.p: t.p., t.t. 
Nasrun Haroen, Ushul Fiqh 1, Jakarta: Logos Wacana Ilmu, 1997.

Rachmat Krisyantono, Teknik Praktis Riset Komunikasi, Jakarta: Kencana Prenada Media Group, 2006.

Tung Desem Waringin, Marketing Revolution, Jakarta: Gramedia Pustaka Utama, 2013.

Wahbah al-Zuhaili, al-Fiqh al-Islami wa Adillatuhu, Suriah: Dar al-Fikr bi Damsyiq, 2002.

Yulistia, M. Ikhsan Indriansyah, Sistem Informasi Penjualan Berbasis Web dan Sms Gateway pada Cv Tricita Computer, STMIK GIMPD. 